Erratum

\title{
Erratum: Skowron Volponi, M. A Vivid Orange New Genus and Species of Braconid-Mimicking Clearwing Moth (Lepidoptera: Sesiidae) Found Puddling on Plecoptera Exuviae. Insects 2020, 11, 425
}

\author{
Marta Skowron Volponi 1,2 (D) \\ 1 ClearWing Foundation for Biodiversity, 01-866 Warsaw, Poland; m.skowronvolponi@uwb.edu.pl \\ 2 Laboratory of Insect Evolutionary Biology and Ecology, Faculty of Biology, University of Bialystok, \\ 15-245 Białystok, Poland
}

Received: 4 August 2020; Accepted: 7 August 2020; Published: 10 August 2020

The author wishes to make the following corrections to this paper [1]:

Acknowledgments: I thank Paolo Volponi for his invaluable assistance in the field which included filming A. piotrii sp. nov. My sincere thank you to Oleg Gorbunov for his consultation on the generic placement of the new species. I thank David Lees from the Natural History Museum in London for allowing me to examine the only known specimen of $A$. metachryseis and Magdalena Czajkowska for her help in obtaining the barcode sequence. Finally, I thank my father, Piotr Skowron, who supported me every step of the way to becoming an entomologist. I would be happy if I ever became half the scientist he is today.

\section{Reference}

1. Skowron Volponi, M. A Vivid Orange New Genus and Species of Braconid-Mimicking Clearwing Moth (Lepidoptera: Sesiidae) Found Puddling on Plecoptera Exuviae. Insects 2020, 11, 425. [CrossRef] [PubMed]

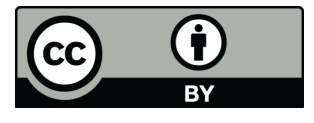

(C) 2020 by the author. Licensee MDPI, Basel, Switzerland. This article is an open access article distributed under the terms and conditions of the Creative Commons Attribution (CC BY) license (http://creativecommons.org/licenses/by/4.0/). 